building, largely in conjunction with international partners. Much more could be made of all these City of Knowledge assets with additional public and private sector support. Close collaboration, as yet lacking among the City of Knowledge institutions, would also help boost productivity.

\section{A WAY FORWARD}

Three macroelements and various smaller initiatives are key to turning around Panamanian higher education. First and foremost is the need for recognition by government and society of higher education's importance to sustainable national development. Second is the urgency for dismantling the stifling political, legal, and bureaucratic hurdles endemic in the country's systems. The UP must be relieved from higher education oversight, and public funding of higher education and research must extend far beyond the UP. Third, provision of adequate resources is vital and Panama can well afford to pay for developing quality higher education institutions and R\&D that serve national economic and social needs. To neglect this, given the country's economic success over the decades, is unforgivable and foolish.

Private higher education can play a major role in Panama's higher education development and several institutions are beginning to do so in visible and important ways. For all institutions, relevant quality controls and freedom to innovate are indispensable, though neither is well governed at the moment. Finally, internationalization is as central to Panama's academic future as it has been to its economic development and must be advanced accordingly. Potential institutional partners for higher education and research are readily available worldwide- - what is required on the Panamanian end is some strategic planning, additional investment, and promotional selling. The City of Knowledge is a fortuitously placed national asset for pushing this agenda and should be better leveraged to this end.

Utilizing Panama's geographic advantage to propel its lagging higher education and research base is imperative for maintaining economic growth and social stability. As banking, logistics, and tourism have been pushed toward world-standard performance, so must happen with Panama's universities if the country is to stake a significant claim to participation in the global economy.

DOI: http://dx.doi.org/10.60I7/ihe.20I9.97.10789

\section{Kenyan Universities: On the Brink of Financial Insolvency}

\author{
ISHMAEL I. MUNENE
}

Ishmael I. Munene is professor in the Educational Leadership Department, Northern Arizona University, US. E-mail: Ishmael.Munene@ nau.edu.

T $\mathrm{t}$ is crunch time for universities in Kenya: for the last three 1 years, the sector has been reeling under a financial crisis of unprecedented proportions, raising questions about its long-term sustainability. So desperate is the situation that universities are unable to cover basic operating expenses like payment of salaries, utilities, and statutory contributions including income tax and pension funds. One private university has been ordered to close by regulators, owing to financial insolvency, while two other private universities have two years to clear all their debts or face a similar fate. The public university system debt stands at US\$IIO million, with the debt of the premier public university at over US\$Io million.

The current crisis echoes the financial catastrophe of the mid-I980s to mid-I990s, when the public university system almost went under owing to state budgetary cuts and the introduction of tuition fees and other market-based strategies. It is ironic that a university system that ten years ago was well funded with tuition revenues should now be on the brink of bankruptcy. The prevailing financial crisis is the result of an interplay of two forces: macro-level policy reforms with system-wide ramifications, and micro-level institutional governance malpractice. The former encapsulates system growth, inequities in enrollment growth, quality enhancement strategies, the failure of the market model, and decreased state support, while the latter includes weak institutional systems of financial governance.

\section{System-Wide Policy Challenges}

Uncoordinated system-wide growth has shrunk the tuition revenue available to most universities. The initial surge occurred in response to an unprecedented demand for higher education after its liberalization in the mid-I990s. From four public and one private universities in the mid-I990s, the number of universities currently stands at $6_{3}$, of which 33 are public and 30 private. Around 70 percent of the public universities were established during the 20I2-20I3 academic year. The rate of university growth, however, has far exceeded the rate of demand for higher education, which plateaued in recent years. This unchecked growth in the number of universities translates into less tuition revenue available to each institution. 
Student enrollment has grown exponentially from Io,000 students in I990 to 539,749 today. Of these, 86 percent are enrolled in public universities, particularly in the top five. This pattern of enrollment has left most private universities operating at only 50-60 percent of their capacity, reducing tuition revenue-given that private universities charge higher tuition, many students choose to study in public institutions. In addition, the newer public universities established in marginal areas have failed to attract sufficient enrollment owing to location and lack of name recognition. Thus, while the growth of the system has absorbed the demand, it has also caused inequities within this tuition-dependent educational environment.

Recent moves to stave off quality decline have also led to a decrease in tuition-paying students. When the state eradicated cheating in national high school exams two years ago, the number of candidates who qualified for university admission dropped by almost 40 percent. Ever since, the number of qualified students is only sufficient for enrollment in state universities (the preferred destination for most high school graduates, owing to lower tuition fees). Also for this reason, the number of qualified students seeking to join private universities, and associated tuition revenue, has declined significantly.

Similarly, quality improvement measures have led the Commission for University Education (CUE) to restrict institutional growth at low-quality branch campuses, especially at public universities. These campuses, employing adjunct faculty without terminal degrees and located in various urban centers across the country, have been an important conduit for universities to increase enrollment and raise revenues at minimal costs. The enactment of stringent licensing requirements for campus operations caused many of them to shut down, depriving universities of an important source of revenue. One public university had so of its I 5 branch campuses shut down.

Ominously, the failure of the market model as a strategy to fund universities has cast a dark spell on neoliberal policies as an alternative to state financing. No university in Kenya has developed a robust market-based revenue generation system besides tuition fees to support the bulk of its operations. Anticipated revenues from research grants, consultancy, industrial partnerships, and sale of goods, among others, have failed to materialize, as universities lack the capacities to tap into these resources. While universities in advanced nations get income from these alternative sources, Kenya, like many African countries, lacks the economic capability to support such developments.

Declining state funding for public universities has also contributed to the current crisis. Owing to increased pressure on the state budget, the government has scaled down its financial support to public universities. In the current financial year, for instance, the public university system budget was cut by nearly US\$300 million, as the government implements austerity measures to stave off an imminent economic meltdown. Public universities received US\$I.03 billion in funding against a request of US\$I.3OI billion. This move will intensify job cuts, hiring freezes, and reductions in research and travel expenditures.

\section{Failures of Institutional Financial Governance}

According to published reports, prudent management of financial resources is undoubtedly lacking at Kenyan universities. A key finding of various investigative reports is outright theft and misappropriation of funds. For instance, a private religious university had a surplus five years ago, but is now on the verge of bankruptcy with a debt of around US\$4 million, owing to theft. Two other religious uni-

\section{Uncoordinated system-wide growth has shrunk the tuition revenue available to most universities.}

versities have experienced student strikes and disruptive changes of leadership as a result of irregularities in the management of their financial resources. Public universities have also had their share of financial improprieties. They have been cited by the government auditor-general for misappropriation of resources and poor investment choices. For example, they hired permanent staff based on projected growth in the enrollment of self-sponsored students - which turned out be unrealistic. One public university opened two branch campuses outside the country at the cost of nearly US\$7 million, but because of regulatory violations these campuses were shut down by authorities before they could operate fully and break even.

\section{THE FUture}

Alleviating the financial stress currently faced by the Kenyan university sector requires an immediate infusion of cash, but for a long-term solution, a multipronged, creative rethinking of financial strategies to fund higher education is needed. This involves a well thought-out and structured state support for both public and private universities, transparency in financial decision-making at the institutional level, separating ownership from management at private universities, tying budget decisions to realistic enrollment 
trends, and hiring financial managers rather than academics-as is the case currently-to steer financial decisions.

DOI: http://dx.doi.org/10.60I7/ihe.2019.97.10789

\section{Exploring Equity in Higher Education Systems: Reflec- tions from Argentina and Chile}

\section{Ana García de Fanelli}

Ana García de Fanelli is a senior research scholar of the National Scientific and Technical Research Council (CONICET) at the Center for the Study of State and Society (CEDES) in Buenos Aires, Argentina. E-mail:anafan@cedes.org.

P ublic debates on equity in higher education usually focus on the impact of admissions and funding policies on a system as a whole. First, it is assumed that the more selective admission criteria and procedures are, the fewer the opportunities will be for lower-income students to access higher education. Second, it is assumed that the cost sharing of undergraduate studies through tuition fees can reduce the chance of less privileged social strata pursuing higher education. Although both premises are true, two additional factors can significantly affect equity in higher education: the capacity of the secondary school and undergraduate levels to retain and provide high-quality education to lower-income and culturally disadvantaged students; and institutional differentiation, which results in vertical stratification in terms of status, with lower-income students attending low-quality institutions.

\section{Access and Funding in Argentina and Chile}

We can illustrate the complexities of the interaction between policies and equity outcomes with two cases from Latin America, which exhibit polarized access and funding policies. Argentina has a nonselective admissions policy for most undergraduate programs (e.g., no entrance exam or maximum number of vacancies) and these same programs are tuition-free in the public sector, which, consequently, has the highest proportion of the enrollment (75 percent of total enrollment in 20I5). The Chilean system, in contrast, is based on selective admissions policies and significant tuition fees in the context of a considerably privatized higher education market structure (in 20I7, 84 percent of enrollment was in the private sector). In principle, we should expect better equity outcomes in Argentina than in Chile.

However, the evolution of the participation rates of the lowest income quintile in these two countries does not reflect this assumption. Chile has rapidly improved access to higher education for students belonging to the lowest strata, surpassing Argentina's net enrollment rate (NER). According to data based on National Household Surveys compiled by the Socio-Economic Database for Latin America and the Caribbean (SEDLAC) in 20I5, the lowest income quintile's NER was 29 percent in Chile and I9 percent in Argentina. Ten years earlier, these same rates were 13 and 16 percent, respectively. Moreover, in 20I5, the ratio between the top quintile's and the bottom quintile's participation in higher education was 2.2 in Chile and 2.8 in Argentina.

These participation indicators do not necessarily imply that Chilean higher education is in all aspects more equitable than that of Argentina, but they call attention to the complexity of the equity challenge in the context of massification and differentiation of higher education. In addition, both systems show marked inequalities. In order to understand better the factors that impinge on equality, we need to examine the two issues mentioned above: the chances that lower-income students have of finishing secondary school and persisting in their undergraduate studies, and the types of institutions that they can attend.

\section{Secondary SCHOOl Completion and Undergraduate DROPOUT RATES}

The graduation rate at the secondary school level clearly explains why Argentina lags behind Chile in terms of higher education NER of lower-income students. According to OECD data, the 2015 upper secondary school graduation rate in Chile was 90 percent, while it was 6r percent in Argentina. In terms of quality, PISA results show that Chile has achieved better marks and improvements over time than Argentina, although these are still below the OECD average. Therefore, in the context of low graduation rates and poor quality achievements at the secondary school level, Argentina's open access and tuition free policies cannot foster inclusion in undergraduate higher education.

In both countries, the poor academic results of lowerincome students hinder their progress in undergraduate programs and result in higher dropout rates during the first year of study. According to estimates of the Chilean Higher Education Information Service (SIES), the first-year dropout rate for the 2008-20I2 cohorts were around 30 percent. The data showed greater dropout rates among lowerincome students with less educated parents and students who had graduated from subsidized private or municipal/ 